\title{
Green Digitalization in the Electric Power Industry
}

\author{
Julia Turovets \\ Expert, Digital Economics Centre, yturovecz@hse.ru
}

Liliana Proskuryakova

Deputy Laboratory Head, Laboratory for Science and Technology Studies, lproskuryakova@hse.ru

Anna Starodubtseva

Research Assistant, Laboratory for Science and Technology Studies, astarodubtseva@hse.ru

Institute for Statistical Studies and Economics of Knowledge at the National Research University Higher School of Economics

(HSE ISSEK), 11, Myasnitskaya str., Moscow 101000, Russian Federation

\section{Vincenzo Bianco}

Associate Professor, vincenzo.bianco@unige.it

Genova University, Via All'Opera Pia 15/A, 16145 Genova, Italy

\begin{abstract}
$\mathrm{T}$

he lasting global economic downturn caused by the COVID-19 pandemic allows decision-makers and societies to re-think the basis and drivers of economic growth, laying the foundation for sustainable development. The green economic recovery can take place with a leading role played by the energy industry. This paper focuses on the application and desired effects of green digital technologies in the electric power industry in ten countries - the largest electricity producers and consumers. This study is designed in the framework of the sectoral innovation systems concept. The research tasks were addressed first through horizon scanning (the analysis of

research and analytical publications). Second, the green digitalization indicators for the electric power industry in the selected countries were identified with the use of statistical and other available reliable data and compared. Third, a comparative analysis of national strategic documents was performed, along with corporate tasks and indicators that reflect the digital transformation at micro level. As a result of this study, key trends and three models of green digitalization at the national level were identified, the prerequisites and potential social and economic effects of the application of these technologies in electric power industry were described.
\end{abstract}

Keywords: digital technologies; green technologies; energy industry; sustainable development; economic recovery; Internet of Energy; smart grid

Citation: Turovets J., Proskuryakova L., Starodubtseva A., Bianco V. (2021) Green Digitalization in the Electric Power Industry. Foresight and STI Governance, 15(3), 35-51. DOI: $10.17323 / 2500-2597.2021 .3 .35 .51$ 


\section{Introduction}

The protracted global economic downturn caused by the COVID-19 pandemic is changing the understanding of growth sources and the drivers that determine the long-term reduction in adverse effects on the environment and climate. The digitalization of various industries which began even before the pandemic appreciably accelerated in 2020 and became a major trend contributing to increased technological and economic efficiency, labor productivity, more accurate planning, a reduced accident rate, and the promotion of green growth [Midttun, Piccini, 2017; IEA, 2020b; Montevecchi et al., 2020].

The fuel and energy sector plays an important role in the green post-crisis economic recovery [Barbier, 2020; Noussan et al., 2021]. Given the growing demand for electricity and the specifics of the sector's development, the electric power industry is of particular importance [IEA, 2020a; IRENA, 2019]. For the decade of 2016-2025, the potential growth of valueadded due to digitalization is estimated at $\$ 1.3$ trillion [WEF, 2016]. Like other segments of the fuel and energy sector, the electric power industry is affected by a number of trends:

- accelerated growth in generation from and investments in renewable energy sources (RES);

- the promotion of energy saving and energy efficiency against the background of a growing demand for energy resources;

- restructuring of producer-consumer relations due to the emergence of smart grids and the internet of energy.

The growing share of electricity in the global energy balance allows one to assess the prospects for related markets. Cutting-edge technologies, such as digital substations, increase the efficiency of generation, reduce transmission losses (especially over long distances), and optimize energy flows. Digital energy consumption management based on the use of smart meters reduces the load during peak hours and the costs for various consumer groups.

The proliferation of inexpensive, reliable, and environmentally friendly energy sources in many countries is associated with supplying energy-poor regions with "clean" electricity from local renewable sources and the construction of smart mini- and microgrids. ${ }^{1}$ The active introduction of distributed, autonomous, and individual generation is also taking place in Russia. Many companies are switching to in-house generation: their share in the total electricity output exceeded 5\% in 2018 and continues to grow at about $3 \%$ per year ${ }^{2}$ [Russian Ministry of Energy, 2019]. This trend is facilitated by the development of high-capacity energy storage technologies and the reduction of their costs, along with reduced costs of rooftop solar panels and solar-wind installations for personal use. The emerging risks for Russia are associated with the planning and construction of generation facilities, especially given the existing surplus capacity.

Digitalization strategies for the fuel and energy sector, first of all the electric power industry, play a key role in the global proliferation of the green economy due to increased resource efficiency and the expansion of clean energy sources. No generally accepted understanding of this process in relation to traditional industries has yet emerged in the literature [OECD, 2019a]. The existing studies only emphasize the need for an integrated approach to considering its features at various levels [IEA, 2017; OECD, 2019b].

The sectoral innovation systems concept, widely applied to studying the use of technologies in various sectors [Malerba, 2002], served as the theoretical basis of this study. The key characteristics and effects of applying green digital technologies in the electricity transmission and distribution segment are examined, at the national and sectoral levels. A comparative analysis of the industry's transformation in ten countries - the leaders in electricity generation - was conducted (China, the US, India, Russia, Japan, Canada, Germany, Brazil, South Korea, and France). Three models of the digital transformation in the electric power industry at the national level are proposed and the main effects of this process are assessed.

\section{Main Areas of Green Digitalization in the Electric Power Industry}

The digitalization of traditional sectors of the economy is a relatively new vector of research, with a growing number of scientific and analytical publications [Beier et al., 2017; Müller et al., 2018; Teece, 2018]. This topic is addressed in the framework of broader concepts and phenomena, such as Industry 4.0, smart manufacturing, the internet of things (IoT), cyberphysical systems, and platform economy [Kang et al., 2016; Ghobakhloo, 2018; Kamble et al., 2018]. Digital technologies' effects are very much specific to various economies, industries, and countries due to the infrastructural nature of the industry, its major economic and social consequences, and growing demand from emerging industries, in particular the data storage and processing segment [Gatto, Drago, 2020; Tripathi, Kaur, 2020]. The development of the electric power industry is also affected by regulatory constraints caused by global environmental challenges [Newberry, 2001; Cavanagh, 2021].

Digitalization helps optimize the operation and maintenance of power grids. New services are emerging, energy trading is being automated. Renewable energy systems are being decentralized [Graf, Jacobsen, 2021; BDEW, 2019]. Smart (actively adaptive) networks and

https://www.un.org/sustainabledevelopment/ru/energy/, accessed on 28.03.2021.

https://minenergo.gov.ru/node/532, accessed on 19.02.2021. 
sensors, the internet of energy, virtual power plants, digital substations, distributed ledger systems (blockchain), and digital platforms are gaining popularity [Dellermann et al., 2017; Ketter et al., 2018; Adeyemi et al., 2020; Menzel, Teubner, 2020]. Each of the above areas use a specific set of technologies [KAS, 2020]. Smart grids integrate various devices used by energy producers, suppliers, and consumers [Ketter et al., 2018; Bertolini et al., 2020]. Smart meters are at their core: they monitor consumption in real time and transmit data to the supplier to help make decisions about infrastructure optimization, and thus manage energy consumption [Waite et al., 2017; Ketter et al., 2018]. Smart devices also include sensors for monitoring the electricity quality [Bagdadee et al., 2020], power transmission losses [Song et al., 2017], the state of underground infrastructure [Rodríguez et al., 2020], automating system management [Wertani et al., 2020], monitoring the condition of equipment [Dileep, 2020], and so on.

Blockchain technologies are finding wide application in creating secure digital environments [Carvalho, 2015; Adeyemi et al., 2020; Zhu et al., 2020]. Such systems monitor operational processes (e.g., the operation of devices which control the power grid voltage), identify deviances, and prevent interruptions in supply and unforeseen situations [Shahidehpour, Fotuhi-Friuzabad, 2016]. Participants' interactions are facilitated by smart contracts which make transactions secure and allow one to manage digital assets (tokens), bill, identify parties, and provide access using modern encryption algorithms [Andoni et al., 2019; Adeyemi et al., 2020]. In new segments of the electric power industry, first of all RES, distributed ledger technologies are applied to monitor the entire value chain. Consumers can sell surplus electricity they generate (the prosumer concept) [ $\mathrm{Zhu}$ et al., 2020]. Cryptocurrencies (SolarCoin, EverGreenCoin, EcoCoin, EECoin, NRGcoin [Andoni et al., 2019]) reduce the role of intermediaries in electricity supply. So far such projects remain in pilot mode [Adeyemi et al., 2020]. Carbon dioxide emission quotas can also be traded, which is especially important against the background of increasingly strict climate-related regulations [Andoni et al., 2019]. The RES infrastructure includes virtual power plants which ensure a stable level of total generation and supply. It is an operatorcontrolled system of small generating facilities linked by open interfaces [Dellermann et al., 2017].

Digital platforms reduce the risks for individual participants and provide personalized services for them. There are electricity platforms which connect retailers and consumers (B2C), or customers with each other (C2C); plug-sharing platforms; electric and hybrid vehicle charging devices able to return surplus energy back to the network (vehicle-to-grid, V2G), etc. They can flexibly manage the network load. Operators regulate participants' activities, whose roles can change. For example, a utility company can act on different platforms as electricity seller, buyer, or service provider [Menzel, Teubner, 2020].

The industry digitalization's drawbacks include increased requirements for information security, the need to attract significant capital investments with a long payback period, and problems with integrating new devices into the existing infrastructure [Edelstein, Kilian, 2007]. Technological innovation and consumer involvement in demand management require new digital competencies. The pace of digitalization is largely determined by the quality of regulation and market maturity, including the security of data storage and exchange systems and the compatibility of information systems and equipment [Epiphaniou et al., 2020; Anderson, El Gamal, 2017; European Commission, 2017].

The legal frameworks for and the principles of involving consumers in energy trade are becoming a new management area. Industry standards for applying advanced technologies are being developed [Afanasyev et al., 2019]. Establishing the rules for processing and storing large amounts of data by industry organizations requires a special effort [Adeyemi et al., 2020]. Digitalization will increase companies' productivity. According to certain forecasts, ignoring this process will lead to every fourth electricity supplier going bankrupt by 2025 [Schwieters et al., 2016; Menzel, Teubner, 2020]. Digital technology platforms can change the investment model's focus from a limited number of large programs to a portfolio of small consumer-initiated projects [Menzel, Teubner, 2020]. The scale of the labor market transformation caused by the introduction of digital technologies will be comparable to the impact of liberalization and job cuts. For example, during the reform period of 1998-2007, the number of jobs in the German electric power sector decreased by 20\% [Graf, Jacobsen, 2021]. Approaches to studying the digital transformation in various industries are still being developed. A range of quantitative and qualitative analysis techniques are being tested [European Commission, 2019b; Zaoui, Souissi, 2020]. Most of the research is focused on the application of specific digital technologies and their technical and economic parameters [Ketter et al., 2018; Xiong et al., 2018; Adeyemi et al., 2020; Ahmad et al., 2021; Bagdadee et al., 2020; Bertolini et al., 2020; Dileep, 2020] as well as institutional restructuring at the sectoral and national levels [Dellermann et al., 2017; Menzel, Teubner, 2020; Graf, Jabobsen, 2021]. Few studies compared the various aspects and effects of digitalization. This paper fills the gap by summarizing the trends, challenges, and effective solutions for the green digital transformation of the electric power industry.

\section{Methodology and Design of the Study}

The research toolkit is comprised of horizon scanning, case studies, expert interviews, company executive 
surveys, and collating available statistics. The analysis of scientific publications and predictive analytical materials issued by international organizations and the world's leading think tanks in 2017-2020 allowed the authors to identify promising areas for the industry's green digitalization. ${ }^{3}$

A comparative analysis of ten countries' - the world's largest producers and consumers of electricity strategies was carried out to study national digitalization initiatives: China, the US, India, Russia, Japan, Canada, Germany, Brazil, South Korea, and France. The data was structured as follows: country; the title of the policy document describing measures to encourage the application of digital technologies in the industry; key national-level development areas in the sector and the tools used to support digitalization. Using theoretical and practical approaches [Brown, Brown, 2019; Korachi, Bounabat, 2019; Lichtenthaler, 2020], the stages of the digital transformation in the industry were identified, the progress in implementing them in the sample countries described, and a list of the main quantitative indicators drafted. Data sources included the World Bank [World Bank, 2021], the US Energy Information Administration [DOE, 2021], the Statista [Statista, 2021a,b,c] and Autostat ${ }^{4}$ portals, and various scientific and analytical publications.

The suggested approach contributes to comparative studies of the digitalization of electric power industry and can be applied to other segments of the fuel and energy sector.

\section{Green Digitalization as a Priority}

Governments not only encourage digitalization but take steps to diminish its possible negative effects such as job cuts [Graf, Jacobsen, 2021], the emergence of more complex management systems [Ahl et al., 2020], data security threats [Dellerman et al., 2017], an increased regulatory burden on companies, and ambiguous legal frameworks [Soshinskaya et al., 2014]. Large economies, the leaders in the absolute electricity generation output, were included in the sample (Table 1).

For each country, the available industry policy documents were analyzed (published mainly in 20152020). Development strategies, analytical materials on technical, economic, and technological matters, legislation regulating the introduction and application of specific technologies, the adoption of tariffs, and so on were reviewed. Key digitalization characteristics and government policy tools were identified.

In most economies smart grids are at the core of the digital transformation. The introduction of other technologies (IoT, artificial intelligence (AI), cloud technologies, digital twins, etc.) is usually planned in national digitalization strategies which are crosscutting in nature, i.e., they cover a wide range of industries. In some countries including Russia the digitalization strategy for the electric power industry is presented in a separate document.

China remains the world's largest energy consumer and clean energy producer $(30 \%$ share in total generation). Investments are primarily channeled to adapt the network infrastructure for RES, increase conventional power plants' flexibility, manage demand, and develop large-scale energy storage systems. The rapidly growing Chinese electric vehicle market has good prospects for integration into the national energy system. Due to rapidly growing energy consumption, the planned transition to clean energy and carbon neutrality by 2060 will likely remain unaccomplished. This scenario can be avoided by implementing and scaling up all possible digitalization tools [IEA, 2019a].

In the next decade the US will remain among the largest electricity consumers and producers. Gasbased generation will continue to dominate, while the RES share will continue growing and coal-based generation will significantly decrease. Power plants and power systems of all types will have to dramatically improve their productivity through digitalization, efficient resource management, lean production, and the introduction of advanced big data analytical systems. Work process optimization, digitalization, and agile working will help utility companies increase productivity by $3 \%$ and reduce electricity production costs (excluding fuel) by $10 \%-20 \%$ for coal power plants and by $5 \%-15 \%$ for gas ones, with improved safety [McKinsey \& Company, 2019]. The main risks are associated with the loss of jobs, lack of qualified personnel to fill the newly created digital vacancies in the energy sector, and ensuring adequate cybersecurity at the achieved digitalization level. As in Canada, the US regions have significant autonomy in choosing core generation and digitalization technologies, which hinders their integration.

If India maintains its current economic growth rates, in a few years' time it will become the world's biggest energy consumer overtaking China. So far, the main energy sources in the country have been coal and oil; over $80 \%$ of the latter is imported. To meet the demand and reduce import dependence, solar generation is being rapidly promoted and integrated into the grid through digitalization. National priorities are focused on digitalizing the networks (monitoring transient processes, $\mathrm{AC}$ power transmission, etc.) and power distribution systems (based on advanced control systems such as SCADA, ADMS, etc.), automating and designing digital substations (there were

\footnotetext{
The publications were selected using the following keywords: digitization, digital transformation, digital/smart energy, energy power industry; smart meters, internet of energy, energy blockchain platform; green/distributed/renewable energy.

${ }^{4}$ https://www.autostat.ru/news/42999/, accessed on 19.02.2021.
} 
Table 1. Top Electricity Producers in 2019 and a Forecast for 2030

\begin{tabular}{|c|c|c|c|c|}
\hline \multirow{2}{*}{ Country } & \multirow{2}{*}{ Electricity production in $2019, \mathrm{TW}$} & \multirow{2}{*}{$\begin{array}{l}\text { Ranking } \\
\text { position } \\
(2019)\end{array}$} & \multicolumn{2}{|c|}{ Electricity production in $2030, \mathrm{TW}$} \\
\hline & & & Baseline scenario & Energy transition scenario \\
\hline China & 7482 & 1 & 9952 & 9317 \\
\hline US & 4385 & 2 & 4506 & 4153 \\
\hline India & 1614 & 3 & 2461 & 2365 \\
\hline Russia & 1122 & 4 & 1207 & 1146 \\
\hline Japan & 1013 & 5 & 1001 & 958 \\
\hline Canada & 649 & 6 & 690.7 & - \\
\hline Germany & 616 & 7 & - & - \\
\hline Brazil & 615 & 8 & 770 & 711 \\
\hline South Korea & 576 & 9 & - & - \\
\hline France & 570 & 10 & - & - \\
\hline
\end{tabular}

more than 50 of them in the country in 2019), and supporting prosumers and active consumers [Batra, 2019]. The main constraints are associated with high levels of poverty and the rapidly growing economy's dependence on imported oil.

In Russia, with its predominantly gas-fired TPPs, RES account for less than $1 \%$ of centralized energy generation. The industry-related initiatives are incorporated in the broader digitalization agenda set by the national program "Digital Economy of the Russian Federation" in 2019. "The program aims for the integrated development of information infrastructure, personnel, digital technologies, information security, and creating legal and regulatory conditions for the development and implementation of relevant solutions in the economy, society, and public administration. A separate Ministry of Energy project "Digital Energy Industry" complements the above system of measures by increasing power supply reliability and creating a single industry-wide digital platform for real-time data transmission and the collection of reports. ${ }^{6}$ The main constraints in Russia are due to excessive centralization, a focus on developing a unified energy system, an excessive number of intermediary organizations, and a high level of cross-subsidization which hampers making optimal decisions on the ground.

Japan, like Germany, has managed to achieve economic growth while reducing primary energy consumption (relative to the 1990 level). In 2018 the country's energy consumption was predominantly based on oil (about $40 \%$ ), gas (21\%), and coal (26\%). RES and hydropower account for $10 \%$. The share of nuclear generation decreased from 30\% in 2011 to 3\% in 2018 [IEA, 2020d] due to the Fukushima accident, which has caused a major disruption to the national power system. Combined with social factors (first of all the ageing of the population), this led to a gradual restructuring of the energy supply through the application of digital technologies. The socioeconomic development strategy Society 5.0 adopted in $2016^{7}$ provides for analyzing various kinds of big data (on meteorology, power plants' operations, state of electric vehicles' batteries, households' energy consumption patterns) using AI. This will help firms to more accurately forecast and optimize energy consumption, redistributing the load on local sources, increasing energy savings, and reducing the impact on the environment and climate. According to the national Strategic Energy Plan, AI, IoT, virtual and augmented reality, and other advanced technologies will significantly impact the structure of energy consumption. The combined effect of digital solutions, energy storage systems, and renewable energy sources will contribute to achieving the climate-related goals of decarbonizing the economy. The risks associated with the energy transition in Japan include the growing political influence of China and India, increased technological competition, and cybersecurity threats [METI, 2018].

In Canada's primary energy consumption structure, oil and natural gas account for 30\%, hydropower for $25 \%$, coal and RES for 3-4\%, and the rest comes from nuclear power plants. In generation hydropower prevails with an about $60 \%$ share. In terms of hydropower production, the country is behind only China and Brazil [EIA, 2019]. Combining clean energy with digital technologies is expected to reduce both the costs and emissions [The Generation Energy Council, 2018]. The industry digitalization priorities until 2050 include improving energy efficiency, managing demand and consumption, developing smart grids, expanding 
electric vehicle infrastructure, and training personnel. Like other countries with a high level of digitalization and electrification, Canada faces the challenges of ensuring the industry's cybersecurity and sustainability [Canadian Electricity Association, 2019].

The European Digital Strategy which guides Germany, France, Spain, and other EU countries is based on the principles of openness, public participation, sustainable development, competition, and social justice [European Commission, 2021b]. The application of advanced information and communication technologies (ICT) including sensors, big data tools, AI, and IoT are expected to improve the connectivity, efficiency, reliability, and sustainability of energy systems [European Commission, 2021a] by harmonizing cooperation in the scope of the Energy Union ${ }^{8}$ and the Digital Single Market. ${ }^{9}$

In Germany, oil (34\% in 2018), natural gas (23\%), and RES (14\%) dominate the total consumption of primary resources. The country has set the most ambitious goals in the EU regarding the decarbonization of the economy, switching to clean energy sources, using smart meters, and other digital technologies [Gangale et al., 2017]. The steps to achieve them are described in the Act on the Digitisation of the Energy Transition [BMWi, EY, 2019] and the Roadmap for Smart Energy Grids of the Future [BMWi, 2017]. This would require maintaining the system's reliability given the growing share of RES and the transition to active-adaptive networks, protecting personal data, and ensuring the compatibility of digital solutions [BMWi, 2017].

Brazil meets about $50 \%$ of its primary energy demand by burning oil and about 30\% from RES and nuclear energy generation. Hydrogeneration covers up to $70 \%$ of the national electricity demand; up to $80 \%$ of electricity in the country is produced from RES. The Brazilian fuel and energy sector is undergoing major reforms which might change its landscape in the coming decades [WEF, Bain \& Company, 2017]. The national digital transformation strategy E-Digital approved in 2018 [Government of Brazil, 2018] provides for developing smart cities through the application of IoT technologies, especially in areas such as mobility, utility companies' security, and smart energy and water grids. Smart meters, remote control and automated generation systems [WEF, Bain \& Company, 2017], real-time simulators, other forecasting and monitoring technologies, and solutions designed to respond to changes are increasingly applied [RRE, 2017]. Digitalization will facilitate the integration of new RES such as wind and sun into the grid and the development of decentralized energy systems. Particular attention is paid to protecting the core na- tional infrastructure, information (repositories, servers, etc.), and conventional energy (electric power, water supply, oil and gas, etc.) from cyberthreats; this is a joint public-private effort.

In South Korea's energy balance oil and coal prevail, followed by natural gas and nuclear energy. The Renewable Energy 2030 Implementation Plan adopted in December 2017 envisages increasing the share of RES in the total electricity generation from $3 \%$ to $20 \%$ [Hong et al., 2019; IEA, 2020e]. In addition to stepping up solar and wind generation, the $9^{\text {th }}$ Basic Plan for Power Supply and Demand aims to increase the flexibility of energy production, storage, transmission, and consumption, and maintain a high level of security of the energy supply system. Digitalization is also in the focus of the Korea Energy Master Plan 2035 and the Green New Deal 2020 post-crisis recovery strategy. The intention is to move on to managing demand by introducing smart grids and smart meters and increase energy efficiency by upgrading the ICT infrastructure [MOTIE, 2014]. The bottlenecks are the high dependence on imported fossil fuel resources, the geographic isolation of the national power grid, and the large distance between the power generation centers (located in the south of the country) and the main consumption areas. The latter issue is also typical for other countries such as Germany.

Despite the differences in the structure and consumption of primary energy resources and the technological level of the industry, almost all of the above countries see digital technologies as a tool for increasing productivity, switching to clean energy, and decentralizing their energy systems.

\section{National Models and Stages of Digital Transformation in the Electric Power Industry}

The analyzed sources allow one to distinguish between three national models of energy system digitalization. The first is applied in countries with decentralized governance (the United States and Canada) whose regions (states, provinces) have sufficient autonomy to choose the core power generation type and make technological decisions on the basis of market pull. This model allows one to test various approaches and choose the most effective ones, taking into account regional specifics (resources, population density, climate, etc.). National industry associations play a coordinating role in harmonizing the regional systems and solutions. A similar approach applies to developed countries which have sufficient energy resources.

The second digitalization model is adopted by economies highly dependent on imported fossil fuels, such

\footnotetext{
${ }^{8}$ https://ec.europa.eu/energy/topics/energy-strategy/energy-union_en, accessed on 19.03.2021.

${ }^{9}$ https://ec.europa.eu/digital-single-market/en/shaping-digital-single-market, accessed on 16.02.2021.
} 
as India, Korea, Japan, and Germany. There, the accelerated transition to RES is prompted not only by climatic and environmental concerns, but also by the need to increase energy independence. In such a situation digitalization helps improve power systems' stability and sustainability, facilitate energy transfer from generation centers to consumers, and radically increase energy efficiency (technology push).

The third, mixed, model is based both on market mechanisms and directive regulation, depending on the electric power industry segment or the application area of digital solutions. This is typical for Russia, China, and Brazil. Though the government sets digitalization paths, industry companies and regions retain certain freedom in choosing the ways to accomplish the established goals.

The proposed models can be supplemented with two main stages of industry digitalization. The first involves the introduction of smart devices (primarily smart meters) and the creation of smart infrastructure. We mean upgrading the existing power grids and equipment, increasing the efficiency of using tangible assets and companies' processes through the extensive adoption of smart electricity metering systems, and improving the legal framework.

The adoption of smart meters which began about ten years ago, has not yet been completed in some countries (e.g., Brazil) due to regulatory barriers and delays with the development of standards [European Commission, 2011]. US utility tariff policy hinders the implementation of large digitalization projects [DOE, 2015]. By 2018, the number of smart meters was approaching the 100 million mark [BCSE, 2020].

The development of standards and legislative support for their application take considerable time. Countries which have reached the targets for the introduction of relevant regulations move on to the next stage: installing smart and next-generation sensors. For example, another wave of modernization of these devices is expected in China, due to their relatively short (5-8 years) life cycle, which should create stable domestic demand at 55-60 million units a year [BMWi, 2020a]. In Canada, the share of smart electricity meters has already reached $82 \%$ [Natural Resources Canada, 2018]. In South Korea the first such devices were installed in 2009-2013 in the Jeju province as part of a pilot project which allowed for testing these devices and then selling them on foreign markets (in Peru and Cambodia) [IEA, 2020f].

The second stage affects the entire value chain and involves the transition to clean energy sources. It implies the systemic transformation of the electric power industry through the application of digital technologies and clean energy, the construction of distributed energy grids and smart mobility infrastructure (including for electric vehicles), smart energy systems for buildings, and an increased range of digital services. A lot of innovative solutions are applied at this stage, such as predictive analytics based on machine learning algorithms, the automation of mutual settlements using distributed ledger systems, digital energy trading platforms [Cardenas et al., 2014], advanced energy management systems, and cross-cutting digital platforms [Vaio et al., 2021; Menzel, Teubner, 2020]. Digitalization affects consumers, suppliers, and partners of transmission and distribution companies.

Modern smart grid infrastructure provides consumers with new services based on online tracking of their energy consumption and its structure and allows for the use of differentiated tariffs. A similar approach is being taken in France where Linky meters support the management of low-voltage grids and tariff differentiation, along with accurate monitoring and predictive diagnostics to manage peak loads [European Commission, 2020]. In Brazil, the "white hourly tariff" allows for tracking households' behavior and on the basis of the collected data encourage users to reduce energy consumption during the 18:00 to 22:00 peak period [Dantas et al., 2018; Dranka, Ferreira, 2020]. Global installation of smart meters would require about two billion dollars in investments [Dranka, Ferreira, 2020].

At this stage various digital technologies are introduced along the entire value chain, based on platform solutions. An example is the project of the Chinese electric power corporation SGCC (e-IoT) to create an "Internet of Energy ecosystem" integrating digital platforms, a demand management system, and other tools to improve internal efficiency. In the interests of the consumer, it is planned to develop services for the integration of power distribution and retail systems, and new models of cloud trading in energy resources [Energy Iceberg, 2019].

At each digitalization stage government support measures are applied, which can be divided into three groups: financial, regulatory, and other (Tables 2-4).

Financial tools promote $\mathrm{R} \& \mathrm{D}$ and the application of new technologies. They include grants, subsidies, $\mathrm{R} \& \mathrm{D}$ tax incentives, technology commercialization funds, government procurement, subsidies for purchasing certain products, contests, funding for startups, and special rates and conditions for the use of smart devices.

For example, in Russia in the framework of the National Technology Initiative, the EnergyNet roadmap has been implemented since 2016, which provides grants for the implementation and commercialization of ideas. EnergyNet digital solutions are aimed at optimizing energy consumption. A competent energy policy and targeted competitive incentives will promote them on the domestic and global markets. It is predicted that by 2035 Russian companies' share on 


\section{Table 2. Financial Support of Digital Transformation in the Electric Power Industry}

\begin{tabular}{|c|c|c|}
\hline Area & Mechanism & Country \\
\hline \multirow[t]{6}{*}{$R \& D$} & Energy technology commercialization funds* & US \\
\hline & Energy technology development grants & Germany \\
\hline & Tax incentives for $\mathrm{R} \& \mathrm{D}$ & India \\
\hline & $\begin{array}{l}\text { Grants for development and commercialization of the EnergyNet roadmap projects in the scope of the } \\
\text { National Technology Initiative }\end{array}$ & Russia \\
\hline & Establishing and supporting advanced technology development centers (AI, etc.) & US \\
\hline & $\begin{array}{l}\text { Public-private partnerships to establish energy industry centers of excellence (with the participation of } \\
\text { academia and small and medium business) to conduct R\&D in priority areas }\end{array}$ & France \\
\hline \multirow[t]{9}{*}{$\begin{array}{l}\text { Introduction of } \\
\text { digital solutions }\end{array}$} & $\begin{array}{l}\text { Grants for the upgrading transmission and distribution networks (Smart Grid Investment Grant } \\
\text { program) }\end{array}$ & US \\
\hline & $\begin{array}{l}\text { Grants (special cooperation agreements) to study the potential of next-generation smart grids } \\
\text { (their compatibility with the existing infrastructure) and energy storage technologies (Smart Grid } \\
\text { Demonstration Programme) }\end{array}$ & US \\
\hline & Subsidies to buy electric vehicles & China \\
\hline & Government procurement of electric vehicles to upgrade the conventional vehicle fleet & India \\
\hline & Industry orders for equipment and other products of the sector & Russia \\
\hline & Grants for distributed energy resources integration, storage devices, and electric vehicle projects & Canada \\
\hline & Contests to select companies - leaders in implementing ICT strategies, with prizes & Japan \\
\hline & Start-up support & India \\
\hline & Export development funds for the commercialization of companies' clean energy solutions & Canada \\
\hline \multirow[t]{3}{*}{ Application } & $\begin{array}{l}\text { Differentiated tariffs to regulate peak loads using smart meters, depending on the time of day or } \\
\text { season }^{*}\end{array}$ & France \\
\hline & $\begin{array}{l}\begin{array}{l}\text { Special tariff for interregional (intermunicipal) associations - a reduced rate for transmission within } \\
\text { the association, and a higher one for external transmission }\end{array} \\
\end{array}$ & France \\
\hline & $\begin{array}{l}\text { Special conditions for the implementation of smart meters when using a certain type of tariff (White } \\
\text { Hourly Tariff)* }\end{array}$ & Brazil \\
\hline
\end{tabular}

global markets will reach $3 \%-12 \%,{ }^{10}$ while their annual revenues will amount to $\$ 40$ billion. ${ }^{11}$

Regulatory tools include legal requirements for handling and using devices and data. They involve certification rules, data availability, uniform standards, and "regulatory sandboxes". For example, German, French, Japanese, and other legislations have requirements for the certification of smart devices [European Commission, 2019a].
The third group of tools comprises other support measures including recommendations on technology application, developing cybersecurity standards and digitalization indicators, promoting consumer involvement in the development of energy supply platforms, building open data infrastructures, setting up digital platforms for electricity trading, developing new business models, and launching pilot energy supply projects.

\section{Table 3. Regulatory Incentives for the Digitalization of the Electric Power Industry}

\begin{tabular}{|l|l|}
\hline \multicolumn{1}{|c|}{ Mechanism } & \multicolumn{1}{c|}{ Country } \\
\hline Mandatory certification requirement for smart devices (meters and hubs)* & $\begin{array}{l}\text { Germany, France, } \\
\text { Japan }\end{array}$ \\
\hline Regulatory sandboxes as part of demonstration projects to test new energy supply models & South Korea \\
\hline Legal requirement to make available data on electricity transmission on retail market & US \\
\hline Legal requirement to set up information systems for managing power grid safety & Germany \\
\hline Legal right of distributor organizations to set up concession electric vehicle charging stations on their territory & Brazil \\
\hline $\begin{array}{l}\text { Granting access to various data on storage, network infrastructure, and meteorology at regulator's request, } \\
\text { using API }\end{array}$ & France \\
\hline Online national energy code compliance system for planning and construction of buildings & India \\
\hline $\begin{array}{l}\text { Unified data standard, including data format and protocol, for use by power grid enterprises (Green Button or } \\
\text { Energy Services Provider Interface Standard) }\end{array}$ & Canada \\
\hline
\end{tabular}

${ }^{10}$ Including reliable and flexible distribution grids, smart distributed energy and consumer services, and related industry segments (utilities and communal services).

${ }^{1}$ https://www.nti2035.ru/markets/docs/DK_energynet.pdf, accessed on 12.02.2021. 


\begin{tabular}{|c|c|c|}
\hline Area & Mechanism & Country \\
\hline \multirow[t]{4}{*}{ Standardization } & $\begin{array}{l}\text { Development of standardization strategy: roadmap for developing technical standards in the } \\
\text { form of recommendations }\end{array}$ & Germany \\
\hline & $\begin{array}{l}\text { Development of cybersecurity standards, including requirement to report incidents } \\
\text { compromising, actually or potentially, the system's reliability }\end{array}$ & US \\
\hline & Developing guidelines on strengthening the security of the industrial internet of things & China \\
\hline & Annual monitoring of digitization progress & Germany \\
\hline \multirow[t]{4}{*}{$\begin{array}{l}\text { Integrated and } \\
\text { platform solutions }\end{array}$} & $\begin{array}{l}\text { Creating open federated data infrastructure for the integration of centralized and decentralized } \\
\text { infrastructures into a homogeneous environment (joint project GAIA-X) }\end{array}$ & Germany, France \\
\hline & Online platforms offering connection to electricity and gas grids & Russia \\
\hline & $\begin{array}{l}\text { Blockchain platforms for trading in surplus electricity, marketplaces based on market operators' } \\
\text { data }\end{array}$ & Japan, France \\
\hline & New business and energy supply models (Mieterstrom) & France \\
\hline \multirow[t]{5}{*}{ Testing and scaling } & $\begin{array}{l}\text { Living laboratories: testing technologies with a high readiness level in real-life conditions } \\
\text { (existing legal and physical infrastructure) without special regulatory exemptions (SINTEG } \\
\text { program) }\end{array}$ & Germany \\
\hline & $\begin{array}{l}\text { Pilot and demonstration projects to launch platforms and mobile applications based on } \\
\text { blockchain, microgrids, and cloud platforms }\end{array}$ & $\begin{array}{l}\text { US, China, South } \\
\text { Korea }\end{array}$ \\
\hline & $\begin{array}{l}\text { Demonstration programs to support projects aimed at building electric vehicle charging } \\
\text { infrastructure }\end{array}$ & Canada \\
\hline & $\begin{array}{l}\text { Demonstration projects on household energy management systems, energy management in } \\
\text { buildings, virtual power plants }\end{array}$ & Japan \\
\hline & $\begin{array}{l}\text { Identifying best practices for launching and subsequent scaling of pilot projects (Digital electric } \\
\text { grids areas) }\end{array}$ & Russia \\
\hline
\end{tabular}

At the second digitalization stage, the toolset expands due to the large amount of innovations along the entire value chain. A new area of regulation is industry data management [Avancini et al., 2019]. In recent years a number of initiatives received support from national regulators.

The Franco-German integrated project GAIA-X implemented by an international non-profit association aims to create open distributed infrastructure for integrating centralized and decentralized networks into a single environment and develop appropriate regulations and services. As a result, a unified format for storing data on the state of infrastructure facilities and other information will emerge.

Uniform standards will allow for bringing providers of cloud solutions, high-performance computing, edge computing systems, and other market participants together on a common platform, thus expanding the range of available services. The project creates conditions for developing new business models (Landlord-to-Tenant Electricity $\mathrm{Act}^{12}$ ), setting up processing centers, providing data aggregation, and other services [BMWi, 2020b].

Many countries are developing regulations for handling information in the energy sector. In the US there is a legal requirement to make available data on electricity transmission on the retail market [IEA, 2019b]. A similar requirement for open interfaces to access data on electricity consumption, network in- frastructure, and meteorological conditions applies in France [Catapult Energy Systems, 2019].

Regardless of the model, integration into a single network requires strengthening the information security of both hardware and software. Cybersecurity standards applied in the US require suppliers to notify customers of incidents threatening the system's reliability [Federal Register, 2019]. A unified standard adopted in the US and Canada in 2011 known as Green Button (Energy Services Provider Interface, ESPI) includes a format and a data exchange protocol between electricity suppliers and consumers using special applications [Natural Resources Canada, 2018].

Over the course of green digitalization, significant resources are allocated to finance $\mathrm{R} \& \mathrm{D}$ at public research organizations and centers of excellence, often in the form of public-private partnerships. Various incentives are applied to encourage the public to acquire new technologies. In Germany a project is underway to install energy storage systems with solar panels connected to the grid. Individual generation systems can transfer no more than $50 \%$ of the energy produced to the grid. The incentives for companies and individuals include investment grants covering $30 \%$ of the battery costs and a low-interest loan for the remaining $70 \%$. Support is provided to install new solar panels and upgrade existing solar power plants with a nominal capacity under $30 \mathrm{~kW} /$ peak and service life of at least five years [DIW Berlin, 2013].

\footnotetext{
2 The law makes supplying electricity to tenants more profitable for both parties to the lease and for the system operators who receive a surcharge from landlords in the amount of 2.2 to 3.8 cents per kWh. The system encourages the use of RES, in particular rooftop solar panels or combined power and heat generation systems. Previously almost all energy generated this way was supplied directly to the grid and did not reach the tenants due to the complexity of the business model for selling electricity to users and the lack of incentives for system operators. The new business model is particularly popular in regions with high tariffs for grid electricity, such as Berlin or Hamburg.
} 
Electromobility remains a priority development area for the industry in practically all countries. Electric vehicles' appeal is increased by subsidies provided for their purchase. In China in 2019 the relevant infrastructure comprised over 500,000 charging points, which is $50 \%$ more than a year earlier. China accounts for $50 \%$ of global electric vehicle sales [BMWi, 2020a]. Electric vehicles with the ability not only to charge from the grid, but also give electricity back in line with the vehicle-to-grid (V2G) principle have an advantage [Clement-Nyns et al., 2011; Bibak, TekinerMoğulkoç, 2021].

The ELBE project (Hamburg, Germany) aims to install over 7,400 smart electric vehicle charging stations based on the distributed system principle. The program participants can expect compensation in the amount of $40 \%-60 \%$ of the equipment or network modernization costs until September 2022, provided that the new stations are compatible with the city operator (so the latter will be able to adjust electricity consumption, including during peak hours) [IRENA, 2019; IEA, 2019c].

"Regulatory sandboxes" provide an opportunity to test new technologies under a special legal regime. In the case of the electric power industry, this involves new models for energy services provision [IEA-ISGAN, 2019]. In contrast, living laboratories are designed to test technologies with a high readiness level in reallife conditions, including the existing legal frameworks [Ahl et al., 2020]. SINTEG is an example of a living laboratory: a program for the testing and subsequent scaling of infrastructure projects for RES generation in five German regions.

For consumers, there are various electronic platforms which simplify connecting to electricity and gas grids (Russia) ${ }^{13}$ [Russian Ministry of Energy, 2019b] or trading in surplus generated electricity, and marketplaces based on market operators' data (Japan, France) [SETIC, 2018].

To compare the productivity of national green digitalization models on the basis of the results of literature analysis, the following indicators were selected:

- average duration of power outages [Adeyemi et al., 2020; Ahmad et al., 2021; Dileep, 2020] as a reliability criterion for relevant services;

- average share of electricity losses [Xiong et al., 2018; Leiden et al., 2021] as an indicator measuring the state of power grid equipment (affects the rate of digital technologies' application);
- share of smart meters in the total number of meters [Adeyemi et al., 2020; Bertolini et al., 2020; Havle et al., 2019];

- share of electric vehicles in the country's total vehicle fleet [Plötz et al., 2017];

- share of filling stations with electric vehicle charging functionality [Ahmad et al., 2021; Hirst, 2020].

These indicator values are presented in Table 5.

Green digitalization indicators in the ten countries selected for analysis vary significantly. The average duration of power outages ranges from 21 to 348 minutes. Japan has the best value, the worst - India and the US (317 and 348 minutes, respectively).

Electricity losses during transmission also indicate the varying efficiency of national grids. In India they amount to about a third of all electricity generated, in Brazil $16 \%$, and in Russia $11 \%$. The lowest values of this indicator are shown by Japan (4\%) and Germany $(4.5 \%)$. In countries with an economy in transition, leakages typically exceed $10 \%$, while in developed countries they remain below $5 \%$. The share of smart meters in their total number ranges from $1 \%$ in India to $98 \%-99 \%$ in some European countries and China.

The lowest disparity was observed in the share of electric vehicles, which does not exceed $3 \%$ of the total vehicle fleet. France and Germany hold the highest value of this parameter with $2.7 \%$ and $2.96 \%$, respectively. However, both in absolute terms and the number of charging stations for this vehicle type, China is in the lead.

In terms of indicators presented in Table 5, Russia lags far behind the EU countries. The duration of power outages for individuals in the country is regulated by law ${ }^{14}$ which limits such periods to 24 consecutive hours and 72 hours per year. Their actual duration in 2019 did not exceed two hours, ${ }^{15}$ but the media frequently reported emergency power outages and their adverse consequences in the Krasnoyarsk, ${ }^{16}$ Pskov, ${ }^{17}$ and other regions. The standards for energy losses during transmission via power grids are approved by the Russian Ministry of Energy. ${ }^{18}$ According to market participants, actual technological losses do not exceed $11 \%$ (see Table 5).

An analysis of national and sectoral strategies allowed the authors to identify the social, climatic, and value effects of green digitalization, along with those potentially emerging in related industries. Social effects in clude reduced costs of new technologies for prosum-

\footnotetext{
${ }^{13}$ https://digital.gov.ru/uploaded/files/tsifrovaya-energetika16x915.pdf, accessed on 09.02.2021.

${ }^{14}$ Power quality standards in general-purpose power supply systems in accordance with GOST 32144 - 2013 ; RF Government Resolutions No. 354 of 06.05.2011 and No. 442 of 04.05.2012.

${ }^{15}$ https://tass.ru/ekonomika/7898243, accessed on 19.02.2021.

${ }^{16}$ https://www.rbc.ru/rbcfreenews/5efec2ab9a79477bda91c7e8, accessed on 19.02.2021.

${ }^{17} \mathrm{https}$ //www.gtrkpskov.ru/news-feed/vesti-pskov/15165-v-pskovskoj-oblasti-proisoshli-massovye-otklyucheniya-elektroenergii.html, accessed 19.02.2021.

${ }^{18}$ According to the RF Government Regulation No. 861 of 27.12.2004.
} 
Table 5. Characteristics of National Green Digitalization Models

\begin{tabular}{|c|c|c|c|c|c|c|c|c|c|c|c|}
\hline Indicator & : & $\tilde{s}$ & $\stackrel{\dddot{\pi}}{\stackrel{3}{\Xi}}$ & 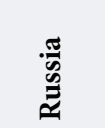 & స్ & 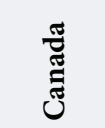 & 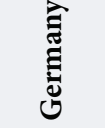 & 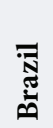 & 总 & 若 & क्ञ๊ \\
\hline $\begin{array}{l}\text { Average duration of power } \\
\text { outages (min.) }\end{array}$ & - & $\begin{array}{c}348 \\
(2018)\end{array}$ & $\begin{array}{c}317 \\
(2018)\end{array}$ & $\begin{array}{c}120 \\
(2019)\end{array}$ & 21 & - & - & - & - & - & - \\
\hline $\begin{array}{l}\text { Average share of electricity losses } \\
(\%)\end{array}$ & $\begin{array}{c}5.9 \\
(2019)\end{array}$ & 5 & 33 & $\begin{array}{c}11 \\
(2019)\end{array}$ & 4 & 9 & $\begin{array}{c}4.46 \\
(2018)\end{array}$ & 16 & - & $\begin{array}{c}6.41 \\
(2018)\end{array}$ & $\begin{array}{c}8.93 \\
(2018)\end{array}$ \\
\hline \begin{tabular}{|l|}
$\begin{array}{l}\text { Share of smart meters in the total } \\
\text { number of meters }(\%)\end{array}$ \\
\end{tabular} & $\begin{array}{c}99 \\
(2018)\end{array}$ & 57 & $\begin{array}{c}1 \\
(2019) \\
\end{array}$ & $\begin{array}{c}10 \\
(2018) \\
\end{array}$ & $\begin{array}{c}67 \\
(2018) \\
\end{array}$ & $\begin{array}{c}80 \\
(2019) \\
\end{array}$ & 15 & - & - & $\begin{array}{c}22.2 \\
(2018) \\
\end{array}$ & $\begin{array}{c}93.1 \\
(2018) \\
\end{array}$ \\
\hline $\begin{array}{l}\text { Share of electric vehicles in the } \\
\text { country's total vehicle fleet (\%) }\end{array}$ & $\begin{array}{c}0.94 \\
(2018)\end{array}$ & $\begin{array}{c}1.9 \\
(2019)\end{array}$ & $\begin{array}{c}0.3 \\
(2019) \\
\end{array}$ & $\begin{array}{c}0.014 \\
(2020)\end{array}$ & $\begin{array}{c}1 \\
(2019)\end{array}$ & $\begin{array}{c}0.14 \\
(2019)\end{array}$ & 2.96 & - & - & 2.7 & 1.31 \\
\hline $\begin{array}{l}\text { Number of filling stations } \\
\text { with electric vehicle charging } \\
\text { functionality (units) }\end{array}$ & $\begin{array}{l}80800 \\
(2019)\end{array}$ & $\begin{array}{l}26000 \\
(2019)\end{array}$ & $\begin{array}{c}250 \\
(2019)\end{array}$ & $\begin{array}{l}1612 \\
(2019)\end{array}$ & $\begin{array}{c}7900 \\
(2019)\end{array}$ & $\begin{array}{c}5000 \\
(2019)\end{array}$ & $\begin{array}{l}27459 \\
(2019)\end{array}$ & - & - & $\begin{array}{l}24950 \\
(2019)\end{array}$ & $\begin{array}{c}5209 \\
(2019)\end{array}$ \\
\hline
\end{tabular}

Sources: authors, based on [Krisher, 2020; Business Standard, 2019; Center on Global Energy Policy, 2019; EIA, 2020a, 2020b; Electric autonomy, 2020; Electrical India, 2018; IEA, 2020c; Energy Efficiency \& Renewable Energy, 2019; Financial Express, 2019, 2020; Gasgoo, 2018; Rivard, 2019; d’Entremont, 2020; Naik, 2020; M2M Research Series, 2018; Nhede, 2020; Spencer-Jones, 2020; Statista, 2021a, 2021b, 2021c; TEPCO, 2015, World Bank, 2021] and Autostat data (https://www.autostat.ru/news/42999/, accessed on 19.02.2021).

ers, the introduction of flexible tariffs for consumers, reduced power outage periods, and the increased availability of electricity in remote and isolated areas. The main climate-related advantage appears to be reduced greenhouse emissions due to more economical and efficient use of energy resources and the transition to RES. The value component amounts to changing consumer behavior patterns and setting sustainable development as a national-level priority instead of economic growth at any cost. The effects in related industries are associated with the emergence of new mobility services and the introduction of new construction standards.

\section{Conclusion}

Unlike other segments of the fuel and energy sector, the electric power industry is at the forefront of the digital transformation - from the introduction of cloud IoT platforms and specialized applications to the optimization of the entire energy production and consumption chain. It can be argued that the industry came as close as possible to the image of the desired digital economy future, proving that it is actually achievable. Digitalization, decarbonization, and decentralization have become key development vectors for the energy industry in most countries. Digital technologies pave the way for new business models and promote the active use of RES.

Three country models and two main stages of digital transformation of the industry were identified, which differ depending on the degree of decision-making centralization, the level of energy imports, and the focus on market pull or technology push. An analysis of national-level strategic documents allowed the authors to determine the social, climatic, and value effects, and assess their impact on related sectors.

The social effects include reduced costs and increased availability of new energy technologies due to the in- dustry development, competition, and government support. The application of digital technologies in the electric power industry contributes to a more efficient consumption of resources by industry players and consumers as well as the reliable and balanced distribution of energy resources. The analysis of big data on consumer behavior allows suppliers to offer flexible tariffs based on energy consumption patterns. Lower costs and lower resource intensity help companies reduce their expenditures and tariffs, while decentralized systems increase the availability of electricity in remote and isolated areas. Companies' efforts to improve economic and technological efficiency directly affect the reliability and security of the electricity supply for consumers. In addition to the above effects, the digitalization of the electric power industry contributes to the sustainable growth of the sector and the whole economy.

Though governments and businesses declare their commitment to reducing the anthropogenic impact upon the environment and climate, at the operational level these goals do not always match the digitalization objectives. The more efficient use of resources (e.g., reducing transmission losses), improved energy efficien$\mathrm{cy}$, and the transition to clean energy highlight the link between digitalization and green growth. However, these transformations will not be possible without a change in values, which largely depends on the informational and educational activities of the state.

The transition to sustainable development and digital technologies leads to changes in many industries, including cross-industry effects such as the emergence of new business models and mobility patterns, the introduction of green standards in construction, and the development of new segments in the ICT industry

This paper was prepared in the scope of a grant provided by the Ministry of Science and Higher Education of the Russian Federation (Grant Agreement No. 075-15-2020-928). 


\section{References}

Adeyemi A., Yan M., Shahidehpour M., Botero C., Guerra A.V., Gurung N., Zhang L., Paaso A. (2020) Blockchain Technology Applications in Power Distribution Systems. The Electricity Journal, 33(8), 106817. https://doi.org/10.1016/j.tej.2020.106817

Afanasyev V.Y., Lyubimova N.G., Ukolov V.F., Shayakhmetov S.R. (2019) Digitalisation of Energy Manufacture: Infrastructure, Supply Chain Strategy and Communication. International Journal of Supply Chain Management, 8(4), 601-609.

Afanasyev V.Ya., Ukolov V.F., Bolshakova O.I., Kislenko N.A., Alekseev A.O. (2020) Adaptive Impact Factor Research Concerning Effectiveness of the Introduction and Use of Digital Twins for Oil and Gas Deposits. International Journal of Criminology and Sociology, 9, 2043-2047. DOI:10.6000/1929-4409.2020.09.239

Ahl A., Yarime M., Goto M., Chopra S.S., Kumar N.M., Tanaka K., Sagawa D. (2020) Exploring Blockchain for the Energy Transition: Opportunities and Challenges Based on a Case Study in Japan. Renewable and Sustainable Energy Reviews, 117, 109488. https://doi.org/10.1016/j.rser.2019.109488

Ahmad T., Zhang D., Huang C., Zhang H., Dai N., Song Y., Chen H. (2021) Artificial Intelligence in Sustainable Energy Industry: Status Quo, Challenges and Opportunities. Journal of Cleaner Production, 289, 125834. https://doi.org/10.1016/j. jclepro.2021.125834

Anderson K., El Gamal A. (2017) Co-Optimising the Value of Storage in Energy and Regulation Service Markets. Energy Systems, 8(2), pp. 369-387. https://doi.org/10.1007/s12667-016-0201-0

Andoni M., Robu V., Flynn D., Abram S., Geach D., Jenkins D., Peacock A. (2019) Blockchain Technology in the Energy Sector: A Systematic Review of Challenges and Opportunities. Renewable and Sustainable Energy Reviews, 100, $143-174$. https://doi.org/10.1016/j.rser.2018.10.014

Avancini D.B., Rodrigues J.J., Martins S.G., Rabêlo R.A., Al-Muhtadi J., Solic P. (2019) Energy Meters Evolution in Smart Grids: A Review. Journal of Cleaner Production, 217, 702-715. https://doi.org/10.1016/j.jclepro.2019.01.229

Bagdadee A.H., Hoque M.Z., Zhang L. (2020) IoT Based Wireless Sensor Network for Power Quality Control in Smart Grid. Procedia Computer Science, 167, 1148-1160. https://doi.org/10.1016/j.procs.2020.03.417

Barbier E.B. (2020) Greening the Post-Pandemic Recovery in the G20. Environmental and Resource Economics, 76(4), 685703. https://doi.org/10.1007/s10640-020-00437-w

Batra P. (2019) Geo Smart Energy - Building a National Integrated Management System. https://geosmartindia.net/speaker/ presentions2019/geosmart\%20energy\%20building\%20national\%20integrated\%20management $\% 20$ system $\% 20 \mathrm{Pankaj} \% 20$ Batra.pdf, accessed 19.02.2021.

BCSE (2020) Sustainable Energy in America. https://www.bcse.org/wp-content/uploads/2020-Sustainable-Energy-inAmerica-Factbook.pdf\#page=121, accessed on 19.02.2021.

BDEW (2019) BDEW Energy Market Germany 2019 in German and English. https://www.bdew.de/media/documents/ Pub_20190603_Energy-Market-Germany-2019.pdf, accessed on 19.02.2021.

Beier G., Niehoff S., Ziems T., Xue B. (2017) Sustainability Aspects of a Digitalised Industry - A Comparative Study From China and Germany. International Journal of Precision Engineering and Manufacturing-Green Technology, 4(2), pp. $227-234$. https://doi.org/10.1007/s40684-017-0028-8

Bertolini B., Buso M., Greco L. (2020) Competition in Smart Distribution Grids. Energy Policy, 145, 111729. https://doi. org/10.1016/j.enpol.2020.111729

Bibak B., Tekiner-Moğulkoç H. (2021) A Comprehensive Analysis of Vehicle to Grid (V2G) Systems and Scholarly Literature on the Application of Such Systems. Renewable Energy Focus, 36, 1-20. https://doi.org/10.1016/j.ref.2020.10.001

BMWi (2017) Electricity 2030 - Concluding Paper. https://www.bmwi.de/Redaktion/EN/Publikationen/electricity-2030concluding-paper.html, accessed on 03.02.2021.

BMWi (2020a) China Energy Transition Status Report 2020. Sino-German Energy Transition Project. https://www. energypartnership.cn/fileadmin/user_upload/china/media_elements/publications/China_Energy_Transition_Status_ Report.pdf, accessed on 03.02.2021.

BMWi (2020b) GAIA-X:Driver of Digital Innovation in Europe. Featuring the Next Generation of Data Infrastructure. https://www. bmwi.de/Redaktion/EN/Publikationen/gaia-X-driver-of-digital-innovation-in-europe.pdf?_blob=publicationFile\&v=8, accessed on 03.02.2021.

BMWi, EY (2019) Barometer Digitalisierung der Energiewende Wichtige Voraussetzungen für die Digitalisierung wurden geschaffen Berichtsjahr 2019. https://www.bmwi.de/Redaktion/DE/Publikationen/Studien/barometer-digitalisierung-derenergiewende-berichtsjahr-2019.pdf?_blob=publicationFile\&v=8, accessed on 15.02.2021.

Brown N., Brown I. (2019) From Digital Business Strategy to Digital Transformation - How? A Systematic Literature Review. Paper presented at the SAICSIT 2019 Conference, September 2019. https://doi.org/10.1145/3351108.3351122 
Business Standard (2019) Nearly 400,000 Electric Vehicles in India, UP Leads Race. https://www.business-standard.com/article/ automobile/nearly-400-000-electric-vehicles-in-india-up-leads-race-delhi-at-2nd-spot-119071500233_1.html, accessed on 19.02.2021.

Canadian Electricity Association (2019) State of the Canadian Electricity Industry. https://cea-ksiu6qbsd.netdna-ssl.com/wpcontent/uploads/2019/02/AIO_Report_2019_Digital.pdf, accessed on 10.03.2021.

Cardenas J., Gemoets L., Ablanedo Rosas J., Sarfi R. (2014) A Literature Survey on Smart Grid Distribution: An Analytical Approach. Journal of Cleaner Production, 65, 202-216. https://doi.org/10.1016/j.jclepro.2013.09.019

Carvalho P. (2015) Smart Metering Deployment in Brazil. Energy Procedia, 83, 360-369. https://doi.org/10.1016/j. egypro.2015.12.211

Catapult Energy Systems (2019) A Strategy for a Modern Digitalised Energy System. https://es.catapult.org.uk/wp-content/ uploads/2019/06/Catapult-Energy-Data-Taskforce-Report-A4-v4AW-Digital.pdf, accessed on 03.02.2021.

Cavanagh R. (2021) Energy Efficiency and Decarbonisation: Priorities for Regulated Utilities. The Electricity Journal, 34(2), 106908. https://doi.org/10.1016/j.tej.2020.106908

Center on Global Energy Policy (2019) Electric Vehicle Charging In China And The United States. https://energypolicy.columbia. edu/sites/default/files/file-uploads/EV_ChargingChina-CGEP_Report_Final.pdf, accessed on 19.02.2021.

Clement-Nyns K., Haesen E., Driesen J. (2011) The Impact of Vehicle-to-Grid on the Distribution Grid. Electric Power Systems Research, 81(1), 185-192. https://doi.org/10.1016/j.epsr.2010.08.007

D'Entremont C. (2020) Why 80 Per Cent of Canadians are Already Using Smart Meters. https://huddle.today/why-80-per-centof-canadians-are-already-using-smart-meters/, accessed on 13.02.2021.

Dantas G.D.A., de Castro N.J., Dias L., Antunes C.H., Vardiero P., Brandão R., Zamboni L. (2018) Public Policies for Smart Grids in Brazil. Renewable and Sustainable Energy Reviews, 92, pp. 501-512. https://doi.org/10.1016/j.rser.2018.04.077

Dellermann D., Fliaster A., Kolloch M. (2017) Innovation Risk in Digital Business Models: The German Energy Sector. Journal of Business Strategy, 38(5), 35-43. https://doi.org/10.1108/JBS-07-2016-0078

Di Vaio A., Palladino R., Pezzi A., Kalisz D.E. (2021) The Role of Digital Innovation in Knowledge Management Systems: A Systematic Literature Review. Journal of Business Research, 123, pp. 220-231. https://doi.org/10.1016/j.jbusres.2020.09.042

Dileep G. (2020) A Survey on Smart Grid Technologies and Applications. Renewable Energy, 146, pp. 2589-2625. https://doi. org/10.1016/j.renene.2019.08.092

DIW Berlin (2013) Policy Efforts for the Development of Storage Technologies in the U.S. and Germany. https://d-nb. info/1153062666/34, accessed on 19.02.2021.

DOE (2015) United States Electricity Industry Primer, Washington, D.C.: Department of Energy. https://www.energy.gov/sites/ $\mathrm{prod} /$ files/2015/12/f28/united-states-electricity-industry-primer.pdf, accessed on 09.02.2021.

DOE (2021) Recovery Act: Smart Grid Investment Grant Programme, Washington, D.C.: Department of Energy. https://www. smartgrid.gov/recovery_act/overview/smart_grid_investment_grant_programme.html, accessed on 27.02.2021.

Dranka G.G., Ferreira P. (2020) Towards a Smart Grid Power System in Brazil: Challenges and Opportunities. Energy Policy, 136, 111033. https://doi.org/10.1016/j.enpol.2019.111033

EC-MAP (2018) New Policy For An Era Of Energy Digitalisation: Power. http://ec-map.org/wp-content/uploads/2018/10/ Power-Whitepaper.pdf, accessed on 27.02.2021.

Edelstein P., Kilian L. (2007) The Response of Business Fixed Investment to Changes in Energy Prices: A Test of Some Hypotheses About the Transmission of Energy Price Shocks. https://repec.cepr.org/repec/cpr/ceprdp/DP6507.pdf, accessed on 19.02.2021.

EIA (2019) Canada. Country analysis. Overview, Washington, D.C.: Energy Information Administration. https://www.eia.gov/ international/analysis/country/CAN, accessed on 09.03.2021.

EIA (2020a) How Much Electricity Is Lost in Electricity Transmission and Distribution in the United States?, Washington, D.C.: Energy Information Administration. https://www.eia.gov/tools/faqs/faq.php?id=105\&t=3\#: :text=The\%20U.S.\%20 Energy\%20Information\%20Administration,in\%20the\%20State\%20Electricity\%20Profiles, accessed on 10.02.2021.

EIA (2020b) U.S. Customers Experienced an Average of Nearly Six Hours of Power Interruptions in 2018, Washington, D.C.: Energy Information Administration. https://www.eia.gov/todayinenergy/detail.php?id=43915\#: :text=In\%202018\%2C\%20 power\%20outage\%20durations, averaged\%205.8\%20hours\%20per\%20customer, accessed on 10.02.2021.

Electric Autonomy (2020) Canada's EV Charging Networks Are Growing at Pace, But More Is Needed. https://electricautonomy. ca/2020/03/02/canadas-ev-charging-networks-2020/\#/analyze?country=CA\&fuel=ELEC\&ev_levels=all\&show_map=true, accessed on 10.02.2021.

Electrical India (2018) Transmission Losses in India. https://www.electricalindia.in/transmission-losses-in-india/, accessed on 13.02.2021. 
Enerdata (2020) Global Energy Statistical Yearbook 2020. https://yearbook.enerdata.net/electricity/world-electricityproduction-statistics.html, accessed on 19.02.2021.

Energy Efficiency \& Renewable Energy (2019) Plug-in Vehicle Sales Accounted for About 2\% of All Light-Duty Vehicle Sales in the United States in 2019. https://www.energy.gov/eere/vehicles/articles/fotw-1136-june-1-2020-plug-vehicle-salesaccounted-about-2-all-light-duty, accessed on 10.02.2021.

Energy Iceberg (2019) Chinese Grids' Transformation to Benefit Digital \& Tech Companies Globally. https://energyiceberg.com/ chinese-grids-transformation-to-benefit-digital-tech-companies-globally/, accessed on 19.02.2021.

Epiphaniou G., Bottarelli M., Al-Khateeb H., Ersotelos N.T., Kanyaru J., Nahar V. (2020) Smart Distributed Ledger Technologies in Industry 4.0: Challenges and Opportunities in Supply Chain Management. In: Cyber Defence in the Age of AI, Smart Societies and Augmented Humanity (eds. H. Jahankhani, S. Kendzierskyj, N. Chelvachandran, J. Ibarra Jimenez), Heidelberg, Dordrecht, London, New York: Springer, pp. 319-345. https://doi.org/10.1007/978-3-030-35746-7_15

European Commission (2011) Smart Grids: From Innovation to Deployment, Brussels: European Commission. https://eur-lex. europa.eu/legal-content/EN/TXT/PDF/?uri=CELEX:52011SC0463\&from=EN, accessed on 19.02.2021.

European Commission (2017) Cyber Security in the Energy Sector. Recommendations for the European Commission on a European Strategic Framework and Potential Future Legislative Acts for the Energy Sector, Brussels: European Commission. https://ec.europa.eu/energy/sites/ener/files/documents/eecsp__final.pdf, accessed on 09.02.2021.

European Commission (2019a) Assessment and roadmap for the digital transformation of the energy sector towards an innovative internal energy market, Brussels: European Commission. https://www.euneighbours.eu/sites/default/files/ publications/2020-03/MJ0220185ENN.en_.pdf, accessed on 09.02.2021.

European Commission (2019b) Digital Transformation in Transport, Construction, Energy, Government and Public Administration, Brussels: European Commission. https://publications.jrc.ec.europa.eu/repository/bitstream/JRC116179/ jrc_digital_transformation_final_on_line_en_baja_resoluci\%c3\%b3n_online.pdf, accessed on 09.02.2021.

European Commission (2020) Integrated National Energy and Climate Plan for France, Brussels: European Commission. https:/ec.europa.eu/energy/sites/ener/files/documents/fr_final_necp_main_en.pdf, accessed on 19.02.2021.

European Commission (2021a) Digitalisation, Brussels: European Commission. https://ec.europa.eu/energy/topics/ technology-and-innovation/digitalisation_en , accessed on 09.02.2021.

European Commission (2021b) The European Digital Strategy, Brussels: European Commission. https://ec.europa.eu/digitalsingle-market/en/content/european-digital-strategy, accessed on 09.02.2021.

Federal Register (2019) Critical Infrastructure Protection Reliability Standard CIP-012-1-Cyber Security-Communications Between Control Centers. https:/www.federalregister.gov/documents/2019/04/24/2019-08236/critical-infrastructureprotection-reliability-standard-cip-012-1-cyber-security-communications, accessed on 09.02.2021.

Financial Express (2019) Powered up: Average electricity cut duration falls in May. https://www.financialexpress.com/economy/ power-up-all-india-average-electricity-cut-duration-falls-in-may/1608184/, accessed on 10.02.2021.

Financial Express (2020) Smart meters: Time to make that smart switch. https://www.financialexpress.com/industry/smartmeters-time-to-make-that-smart-switch/2092936/, accessed on 13.02.2021.

Gangale F., Vasiljevska, J., Covrig, C., F., Mengolini, A., Fulli, G. (2017) Smart grid projects outlook 2017, Brussels: European Commission. https://publications.jrc.ec.europa.eu/repository/bitstream/JRC106796/sgp_outlook_2017-online.pdf, accessed on 09.02.2021.

Gasgoo (2018) China car population reaches 235 million units, Ministry of Public Security. http://autonews.gasgoo.com/china_ news/70015270.html, accessed on 13.02.2021.

Gatto A., Drago C. (2020) Measuring and modeling energy resilience. Ecological Economics, 172. 106527. https://doi. org/10.1016/j.ecolecon.2019.106527

Ghobakhloo M. (2018) The future of manufacturing industry: A strategic roadmap toward Industry 4.0. Journal of Manufacturing Technology Management, 29(6), 910-936. https://doi.org/10.1108/JMTM-02-2018-0057

Government of Brazil (2018) Brazilian Digital Transformation Strategy E-Digital. https://www.gov.br/mcti/pt-br/centrais-deconteudo/comunicados-mcti/estrategia-digital-brasileira/digitalstrategy.pdf, accessed on 09.02.2021.

Graf P., Jacobsen H. (2021) Institutional work in the transformation of the German energy sector. Utilities Policy, 68, 101107. https://doi.org/10.1016/j.jup.2020.101107

Havle B., Dursun M. (2019) Digital Transformation in Energy Industry: A Literature Review for Future Studies. Paper presented at the 3rd International Conference on Data Science and Business Analytics (ICDSBA) 11-12 October 2019. DOI: 10.1109/ ICDSBA48748.2019.00043

Hirst D. (2020) Electric vehicles and infrastructure (Briefing Paper CBP07480). https://commonslibrary.parliament.uk/ research-briefings/cbp-7480/, accessed on 06.07.2021.

Hong J., Kim J., Son W., Shin H., Kim N., Lee W.K., Kim J. (2019) Long-term energy strategy scenarios for South Korea: Transition to a sustainable energy system. Energy Policy, 127, 425-437. https://doi.org/10.1016/j.enpol.2018.11.055 
IEA (2017) Digitalisation and Energy, Paris: International Energy Agency. https://iea.blob.core.windows.net/assets/b1e6600c4e40-4d9c-809d-1d1724c763d5/DigitalisationandEnergy3.pdf, accessed on 09.02.2021.

IEA (2019a) China Power System Transformation, Paris: International Energy Agency. https://iea.blob.core.windows.net/ assets/fd886bb9-27d8-4d5d-a03f-38cb34b77ed7/China_Power_System_Transformation.pdf, accessed on 09.02.2021.

IEA (2019b) Energy Policy of the IEA countries. The United States 2019 Review, Paris: International Energy Agency. https:// webstore.iea.org/download/summary/2829, accessed on 09.02.2021.

IEA (2019c) Project ELBE (incentive programmeme for EV charging infrastructure), Paris: International Energy Agency. https:// www.iea.org/policies/8540-project-elbe-incentive-programmeme-for-ev-charging-infrastructure, accessed on 09.02.2021.

IEA (2020a) Electricity Market Report - December 2020, Paris: International Energy Agency. https://iea.blob.core.windows.net/ assets/a695ae98-cec1-43ce-9cab-c37bb0143a05/Electricity_Market_Report_December_2020.pdf, accessed on 09.02.2021.

IEA (2020b) Energy end-use data collection methodologies and the emerging role of digital technologies, Paris: International Energy Agency. https://iea.blob.core.windows.net/assets/34e2659e-809c-4299-bb51-c0343257af08/Energy_end-use_ data_collection_methodologies_and_the_emerging_role_of_digital_technologies.pdf, accessed on 15.02.2021.

IEA (2020c) India 2020. Energy Policy Review, Paris: International Energy Agency. https://niti.gov.in/sites/default/ files/2020-01/IEA-India\%202020-In-depth-EnergyPolicy_0.pdf, accessed on 07.02.2021.

IEA (2020d) Japan, Paris: International Energy Agency. https://www.iea.org/countries/japan, accessed on 09.02.2021.

IEA (2020e) Korea, Paris: International Energy Agency. https://www.iea.org/countries/korea, accessed on 09.02.2021.

IEA (2020f) World Energy Outlook 2020, Paris: International Energy Agency. https://www.iea.org/reports/world-energyoutlook-2020, accessed on 09.02.2021.

IEA-ISGAN (2019) Innovative Regulatory Approaches with Focus on Experimental Sandboxes, Paris: International Energy Agency. https://www.iea-isgan.org/wp-content/uploads/2019/05/ISGAN_Casebook-on-Regulatory-Sandbox-A2-1.pdf, accessed on 19.02.2021.

IRENA (2019) Electrification with renewables: Driving the transformation of energy services, Abu-Dhabi: IRENA. https:// www.irena.org/-/media/Files/IRENA/Agency/Publication/2019/Jan/IRENA_RE-Electrification_SGCC_2019_preview.pdf, accessed on 09.02.2021.

IRENA (2020) Renewable capacity statistics 2020, Abu-Dhabi: IRENA. https://www.irena.org/-/media/Files/IRENA/Agency/ Publication/2020/Mar/IRENA_RE_Capacity_Statistics_2020.pdf, accessed on 09.02.2021.

Kamble S.S., Gunasekaran A., Gawankar S.A. (2018) Sustainable Industry 4.0 framework: A systematic literature review identifying the current trends and future perspectives. Process Safety and Environmental Protection, 117, 408-425. https:// doi.org/10.1016/j.psep.2018.05.009

Kang H.S., Lee J.Y., Choi S., Kim H., Park J.H., Son J.Y., Do Noh S. (2016) Smart manufacturing: Past research, present findings, and future directions. International Journal of Precision Engineering and Manufacturing-Green Technology, 3(1), 111-128. https://doi.org/10.1007/s40684-016-0015-5

KAS (2020) Sustainable Energy and Digitalisation: Practices and Perspectives in Asia-Pacific. https://www.kas.de/ documents/265079/265128/Sustainable+Energy+and+Digitalisation+Practices+and+Perspectives+in+Asia+Pacific.pdf/ a1a26d16-fa77-ac3f-c688-92d91bca6834?version=1.0\&t=1581407991474, accessed on 19.02.2021.

Ketter W., Collins J., Saar-Tsechansky M., Marom O. (2018) Information systems for a smart electricity grid: Emerging challenges and opportunities. ACM Transactions on Management Information Systems (TMIS), 9(3), 1-22. https://doi. org/10.1145/3230712

Korachi Z., Bounabat B. (2019) Towards a Maturity Model for Digital Strategy Assessment. In: Proceedings of the AI2SD 2019 Conference, Heidelberg, Dordrecht, London, New York: Springer, pp. 456-470. DOI: 10.1007/978-3-030-36674-2_47

Krisher T. (2020) Plug it in: Electric car charging station numbers are rising. https://apnews.com/article/business-u-snews-technology-detroit-electric-vehicles-0dbe44f4626fcfd6b3ccee274980188e\#: :text=There\%20are\%20now\%20 26\%2C000\%20electric,with\%20more\%20than\%2084\%2C000\%20plugs, accessed on 13.02.2021.

Leiden A., Herrmann C., Thiede S. (2021) Cyber-physical production system approach for energy and resource efficient planning and operation of plating process chains. Journal of Cleaner Production, 280, 125160. https://doi.org/10.1016/j. jclepro.2020.125160

Lichtenthaler U. (2020) Building blocks of successful digital transformation: Complementing technology and market issues. International Journal of Innovation and Technology Management, 17(1), 1-14. https://doi.org/10.1142/S0219877020500042

M2M Research Series (2018) Smart Metering in North America and Asia-Pacific. https://www.marketresearch.com/BergInsight-v2702/Smart-Metering-North-America-Asia-12517854/, accessed on 10.02.2021.

Malerba F. (2002) Sectoral systems of innovation and production. Research Policy, 31(2), 247-264. https://doi.org/10.1016/ S0048-7333(01)00139-1 
McKinsey \& Company (2019) Unlocking the value of digital operations in electric-power generation. https://www.mckinsey. $\mathrm{com}$ /industries/electric-power-and-natural-gas/our-insights/unlocking-the-value-of-digital-operations-in-electric-powergeneration\#, accessed on 19.02.2021.

Menzel T., Teubner T. (2020) Green energy platform economics - understanding platformisation and sustainabilisation in the energy sector. International Journal of Energy Sector Management, 15(3), 456-475. https://doi.org/10.1108/ IJESM-05-2020-0022

METI (2018) Strategic Energy Plan. https://www.enecho.meti.go.jp/en/category/others/basic_plan/5th/pdf/strategic_energy_ plan.pdf, accessed on 08.02.2021.

METI (2020) Guidebook on Corporate Governance for Privacy in Digital Transformation (DX) ver.1.0 Formulated. https://www. meti.go.jp/english/press/2020/0828_006.html, accessed on 08.02.2021.

Midttun A., Piccini P.B. (2017) Facing the climate and digital challenge: European energy industry from boom to crisis and transformation. Energy Policy, 108, 330-343. https://doi.org/10.1016/j.enpol.2017.05.046

Mika B., Goudz A. (2020) Blockchain-technology in the energy industry: Blockchain as a driver of the energy revolution? With focus on the situation in Germany. Energy Systems, 12, 285-355. https://doi.org/10.1007/s12667-020-00391-y

Montevecchi F., Stickler T., Hintemann R., Hinterholzer S. (2020) Energy-efficient Cloud Computing Technologies and Policies for an Eco-friendly Cloud Market, Brussels: European Commission. https://www.researchgate.net/profile/Simon_Hinterholzer/ publication/345687292_Energy-efficient_Cloud_Computing_Technologies_and_Policies_for_an_Eco-friendly_Cloud_ Market/links/5faacbcf4585150781066c41/Energy-efficient-Cloud-Computing-Technologies-and-Policies-for-an-Ecofriendly-Cloud-Market.pdf, accessed on 19.02.2021.

MOTIE (2014) Korea Energy Master Plan. Outlook \& Policies to 2035. https://www.motie.go.kr/common/download. do?fid=bbs\&bbs_cd_n=72\&bbs_seq_n=209286\&file_seq_n=2, accessed on 19.02.2021.

Müller J.M., Kiel D., Voigt K.I. (2018) What drives the implementation of Industry 4.0? The role of opportunities and challenges in the context of sustainability. Sustainability, 10(1), 247. https://doi.org/10.3390/su10010247

Naik A.R. (2020) The Math Behind India's Electric Vehicle Charging Infrastructure. https://inc42.com/features/the-math-behindindias-electric-vehicle-charging-infrastructure/\#: :text=According\%20to\%20a\%20MarketWatch\%2C\%20at,expected $\% 20$ to $\% 20$ witness\%20massive\%20growth, accessed on 113.02.2021.

Natural Resources Canada (2018) Smart Grid in Canada. https://www.nrcan.gc.ca/sites/www.nrcan.gc.ca/files/canmetenergy/ pdf/Smart\%20Grid\%20in\%20Canada\%20Report\%20Web\%20FINAL\%20EN.pdf, accessed on 09.02.2021.

Newberry S. (2001) Network structures, consumers and accountability in New Zealand. In: Learning from International Public Management Reform: Part A (eds. L.R. Jones, J. Guthrie, P. Steane), Bingley: Emerald Group Publishing Limited, pp. 257278. https://doi.org/10.1016/S0732-1317(01)11054-7

Noussan M., Raimondi P.P., Scita R., Hafner M. (2021) The Role of Green and Blue Hydrogen in the Energy Transition - A Technological and Geopolitical Perspective. Sustainability, 13(1), 298. https://doi.org/10.3390/su13010298

OECD (2019a) Measuring the Digital Transformation: A Roadmap for the Future, Paris: OECD. https://www.oecd.org/goingdigital/measurement-roadmap.pdf, accessed on 09.02.2021.

OECD (2019b) Vectors of Digital Transformation OECD Digital Economy Papers, Paris: OECD. https://www.sipotra.it/wpcontent/uploads/2019/03/VECTORS-OF-DIGITAL-TRANSFORMATION.pdf, accessed on 14.02.2021.

Plötz P., Sprei F., Gnann T. (2017) What are the effects of incentives on plugin electric vehicle sales in Europe? Paper presented at the ECEEE 2017 Summer Study - Consumption, Efficiency \& Limits. https://www.researchgate.net/publication/318209508_ What_are_the_effects_of_incentives_on_plug-in_electric_vehicle_sales_in_Europe, accessed on 09.02.2021.

Ratnam K.S., Palanisamy K., Yang G. (2020) Future low-inertia power systems: Requirements, issues, and solutions. A review. Renewable and Sustainable Energy Reviews, 124, 109773. https://doi.org/10.1016/j.rser.2020.109773

Rivard G. (2019) Over 40,000 Plug-In Cars Sold in Canada. https://www.guideautoweb.com/en/articles/52849/over-40-000plug-in-cars-sold-in-canada-so-far-in-2019/, accessed on 13.02.2021.

Rodríguez F., Sánchez-Guardamino I., Martín F., Fontán L. (2020) Non-intrusive, self-supplying and wireless sensor for monitoring grounding cable in smart grids. Sensors and Actuators A: Physical, 316, 112417. https://doi.org/10.1016/j. sna.2020.112417

RRE (2017) Digitalisation in the Brazilian Energy Sector: Time for Disruption? https:/digital.hbs.edu/platform-rctom/ submission/digitalisation-in-the-brazilian-energy-sector-time-for-disruption/\#, accessed on 19.02.2021.

Schwieters N., Hasse F., von Perfall A., Maas H., Willms A., Lenz F. (2016) Deutschlands energieversorger werden digital, Frankfurt: PricewaterhouseCoopers. https://www.pwc.de/de/pressemitteilungen/2016/deutschlands-energieversorgerwerden-digital-aber-zu-langsam.html, accessed on 19.02.2021.

SETIC (2018) Digitalisation of the Energy sector. https://publications.jrc.ec.europa.eu/repository/bitstream/JRC113569/setis_ magazine_17_online.pdf, accessed on 09.02.2021. 
SGCC (2019) Internet of Things White Paper. http://www.sgcc.com.cn/html/files/2019-10/14/20191014235609307380194. pdf, accessed on 08.02.2021.

Shahidehpour M., Fotuhi-Friuzabad M. (2016) Grid modernisation for enhancing the resilience, reliability, economics, sustainability, and security of electricity grid in an uncertain environment. Scientia Iranica, 23(6), 2862-2873. DOI: 10.24200/SCI.2016.3995

Song E.Y., FitzPatrick G.J., Lee K.B. (2017) Smart sensors and standard-based interoperability in smart grids. IEEE Sensors Journal, 17(23), 7723-7730. DOI: 10.1109/JSEN.2017.2729893

Soshinskaya M., Crijns-Graus W.H.J., Guerrero J.M., Vasquez J.C. (2014) Microgrids: Experiences, barriers and success factors. Renewable and Sustainable Energy Reviews, 40, 659-672. https://doi.org/10.1016/j.rser.2014.07.198

Statista (2021a) Electric car market share in Japan 2010-2019. https://www.statista.com/statistics/711994/japan-electric-carmarket-share/\#: :text=As\%20of\%202019\%2C\%20approximately\%200.9, and\%202018\%20were\%20expanding\%20rapidly, accessed on 10.02.2021..

Statista (2021b) Electric power transmission loss in China from 2010 to 2019. https://www.statista.com/statistics/302292/ china-electric-power-transmission-loss/\#: :text=Electric\%20power\%20transmission\%20loss\%20in\%20China\%20 $2010 \% 2$ D2019\&text $=$ This\%20statistic\%20represents\%20electric\%20power,to\%20transmission\%20and \%20 distribution\%20resistance, accessed on 13.02.2021.

Statista (2021c) Number of EVSE fast chargers in Japan 2010-2019. https://www.statista.com/statistics/712010/japan-evsefast-charger-stock/, accessed on 10.02.2021.

Teece D.J. (2018) Profiting from innovation in the digital economy: Enabling technologies, standards, and licensing models in the wireless world. Research Policy, 47(8), 1367-1387. https://doi.org/10.1016/j.respol.2017.01.015

TEPCO (2015) TEPCO Power Grid. https://www.tepco.co.jp/en/pg/supply/quality/index-e.html

The Generation Energy Council (2018) Canada's Energy Transition. Getting to our Energy Future, Together. Generation Energy Council Report. https://www.nrcan.gc.ca/sites/www.nrcan.gc.ca/files/energy/CoucilReport_june27_English_Web.pdf, accessed on 10.03.2021.

Tripathi V., Kaur A. (2020) Socially responsible investing: Performance evaluation of BRICS nations. Journal of Advances in Management Research, 17(4), 525-547. https://doi.org/10.1108/JAMR-02-2020-0020

Waite M., Cohen E., Torbey H., Piccirilli M., Tian Y., Modi V. (2017) Global trends in urban electricity demands for cooling and heating. Energy, 127, 786-802. https://doi.org/10.1016/j.energy.2017.03.095

WEF (2016) Electricity: uncovering value through digital transformation, Geneva: World Economic Forum. https://reports. weforum.org/digital-transformation/electricity-an-industry-ready-for-digitisation/, accessed on 09.02.2021.

WEF, Bain \& Company (2017) The Future of Electricity: New Technologies Transforming the Grid Edge, Geneva: World Economic Forum. https://media.bain.com/Images/WEF_Future_of_Electricity_2017.pdf, accessed on 19.02.2021.

Wertani H., Salem J.B., Lakhoua M.N. (2020) Analysis and supervision of a smart grid system with a systemic tool. The Electricity Journal, 33(6), 106784. https://doi.org/10.1016/j.tej.2020.106784

World Bank (2021) Electric power transmission and distribution losses (\% of output). https://data.worldbank.org/indicator/ EG.ELC.LOSS.ZS, accessed on 19.02.2021.

Xiong R., Chen H., Wang C., Sun F. (2018) Towards a smarter hybrid energy storage system based on battery and ultracapacitor - A critical review on topology and energy management. Journal of Cleaner Production, 202, 1228e1240. https://doi. org/10.1016/j.jclepro.2018.08.134

Zaoui F., Souissi N. (2020) Roadmap for digital transformation: A literature review. Procedia Computer Science, 175, 621-628. https://doi.org/10.1016/j.procs.2020.07.090

Zhu Z., Li X., Ding Y., Liu Z. (2020) Demand response capacity constrained optimisation of multicast routing in smart grid. International Journal of Wireless and Mobile Computing, 19(1), 33-41. DOI: 10.1504/IJWMC.2020.109259 